\title{
Sex in the city: gender mainstreaming urban governance in Europe. The case of Sweden and Italy
}

\author{
MARTIN ZEBRACKI
}

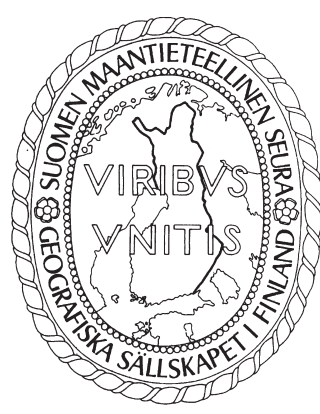

Zebracki, Martin (2014). Sex in the city: gender mainstreaming urban governance in Europe. The case of Sweden and Italy. Fennia 192: 1, pp. 54-64. ISSN 1798-5617.

\begin{abstract}
This article reviews gender mainstreaming in practices of urban governance in Europe by comparing Sweden and Italy, which have distinct welfare-state systems: that of the former is firmly embedded in institutional and social structures, whereas that of the latter is markedly more familistic. This review illustrates this relatively strong contrast case on the basis of a literature and policy analysis, and elaborates how the everyday policies of urban governance regarding the living environment are considerably more gender-sensitive in Sweden than is the case in Italy. The main explanation for this difference lies in Sweden's political socialism and longer socio-democratic tradition of incremental and equity-planning approaches in urban governance, in contrast to Italy's social tradition of rather more conservative corporatism and patriarchal commune tactics. Socio-political and formal-institutional barriers, which are impeding both the top-down and the bottom-up implementation of gender-sensitive initiatives, could be overcome by creating more mental and formal legislative room for urban-based gender mainstreaming. Such room would challenge prevailing patriarchal societal structures and policy narratives.
\end{abstract}

Keywords: Sweden, Italy, gender, gender mainstreaming, urban governance, literature and policy analysis

Martin Zebracki, School of Geography, University of Leeds, University Road, Leeds LS2 9JT, United Kingdom; Cultural Geography Group, Wageningen University, Droevendaalsesteeg 3, Wageningen 6708 PB, the Netherlands. E-mail: M.M.Zebracki@leeds.ac.uk

\section{Introduction: the gendered city}

This research reviews contemporary gender mainstreaming practices of urban governance in Europe, particularly seen in the context of the European Union (EU). A number of urban geographers have recently been critically revisiting cities through gender lenses (e.g. Moss \& Al-Hindi 2008; Jarvis et al. 2009; Raju \& Lahiri-Dutt 2011; Chant 2013). The general critique presented by geographers concerned with gender is that both the field of geography and the practice of urban governance - the latter being the methods of governing and the way of developing and implementing policies at the local level - are too masculinist and gender-blind (cf. Doan 2010). Their argument runs that women's presence in space is highly con- strained by gender roles, and that urban governance in every sphere is oriented towards the needs and routines of especially male city users (Watson \& Gibson 1995; McDowell 1999, see also Walby 2005a, 2005b; Lavena \& Riccucci 2012). In that respect, a good while ago, Monk and Hanson (1982: 44) made a plea for "a more [gender-]fully human geography".

Even though most urban scholars acknowledge that gender equality matters in cities across the world (cf. Eriksson 2010), the topic of gender and urban governance still has a relatively modest position on the academic agenda, whereas the discussion of urban governance with regard to the welfare state and the neoliberal production of new state spaces is highly developed (cf. Jessop 2002; Brenner 2004). What the 'gendered city' in all its 
diversities implies in terms of urban governance and modes of governing remains compelling and debatable (cf. Beall 1996; Huairou Commission and UN-Habitat 2004; Parker 2004; Moss \& AlHindi 2008).

Broadly speaking, a shift has been taking place in cities in the EU from governmental responsibilities to governance-oriented structures. This has led to increased interest in bottom-up initiatives. Presuming that 'good' urban governance (cf. UNCHS 2000; Huairou Commission and UN-Habitat 2004) requires being equitable, sustainable and effective, the question here concerns the extent to which urban governance in Europe is gender-sensitive. In accordance with the criteria of the UNCHS (2000) for 'good' urban governance and sound gender politics in global governance and transnationalism (cf. Meyer \& Prügl 1999; True \& Mintrom 2001), gender mainstreaming governance strives not only to promote the capacity building of particularly women - essentially those in community-based organizations and local authorities (cf. Droste et al. 2005) as well as in transnational advocacy networks (cf. Lang 2009) - but also to include lesbian, gay, bisexual and transgender (LGBT) service providers and users (cf. Stone 2010). On this, Woodward (2003: 84) argues, in respect to town and country planning more widely, that "gender awareness [should be] a given and equality [of sexes] [should be] a constant goal". Accordingly, he states that "mainstreaming suggests that equal opportunities for women and men should no longer be achieved solely through equal-opportunity-earmarked policies. A multistranded and total approach is necessary" (ibid: 66).

European cities are mainly characterized by densely populated areas with a large share of social housing, and by large families, high densities of young people, immigrant populations and ageing cohorts of mostly female residents. Moreover, female-headed households are becoming increasingly common in dense urban areas (cf. Becker 2003; Huairou Commission and UN-Habitat 2004; Anxo et al. 2007) - hence this review's focus on cities. In the light of todays' integrated and governance-oriented urban administration, including bottom-up initiatives, the role of women as specifically both heads of family and potential political leaders is significant and therefore deserves attention in the field of gender mainstreaming.
Europe's different forms of welfare-state system and nation building have shaped a heterogeneous, complex social environment as regards gender sensitivity, also at the urban governance level, which is highly related to the governmentalities at regional and national levels (cf. Esping-Andersen 1990; Hamnett 1996; Dean 1999; Tuori 2007). This article provides a brief policy comparison between Sweden and Italy. The rationale behind this selection is that these two countries have distinct welfare-state regimes and gender-social conditions (cf. Borchorst \& Siim 2008) and are therefore a telling contrast case study.

Sweden has a robustly implemented welfarestate system, whereas Italy's is generally strongly familistic (cf. Droste et al. 2005; Anxo et al. 2007). Ciccia and Verloo (2011) classified Sweden as a full "universal caregiver model" (ibid: 6), while acknowledging that this model does not exist as such, as parental leaves are considered too short even in Nordic countries (see also Pfau-Effinger 2004). Furthermore, as conveyed by Kröger (1997) and Gustafsson and Szebehely (2009), it is appropriate to contemplate Sweden as consisting of multiple welfare communities rather than one uniform welfare state. Sweden's local service provision cannot be typified by a uniform pattern, and local governments have substantial autonomy, which gives them room to manage services like schools and geriatric care via not-for-profit or private actors (cf. Argento et al. 2010).

On Italy, Saraceno (1994) stated that its familialism does not let the state intervene directly in family relations and hence, in the main, leaves families (that is, women in particular) to carry the burden of care. Moving beyond such generalization, Italy also presents a nuanced, differentiated profile in regard to welfare, especially since the local and regional government reforms of the 1990s. Salient anomalies in this respect are the rather centre-left regional and municipal governments of Tuscany, Umbria and Emilia-Romagna, which have historically witnessed policies of equal employment opportunities (cf. Rizza \& Sansavini 2010). They explicitly draw in the rights of women, provide highquality and low-cost childcare, promote social integration of the elderly (women in particular), deliver support to women who have fallen victim to domestic abuse, and so on (cf. ibid.). Comparatively, Sweden and Italy may thus be seen as fairly opposite poles within a continuum between welfare statism and familialism. 
Based on a discourse analysis of academic literature and policy documents, this article addresses the following three research questions. To what extent is the current Swedish and Italian practice of urban governance gender-sensitive? How can the differences between these countries be explained? And how could gender mainstreaming urban governance in Europe be generally advanced? The article first presents a critical conceptual overview of gender mainstreaming urban governance, and then clarifies and reflects upon the gender mainstreaming differences between Sweden and Italy. A number of comparative conclusions are provided, together with some general recommendations for furthering structural frameworks that may enhance gender mainstreaming awareness and implementation within urban governance.

\section{Gender mainstreaming on critical display}

What are the needs of women in the urban built environment, and how do they differ from those of men? And what are the differences within 'the different'? How does urban governance affect women and men differently, and how could it be adapted in order to affect them equally? Urban scholars have been occupied with these and cognate questions for more than 40 years (for further background on the urban gender condition and gender histories across various epistemologies, see Lin \& Mele 2013 and Gabaccia \& Maynes 2013, respectively). Urban policymakers and planners broadly acknowledge that the implementation of policies on equal opportunities and gender mainstreaming is often problematic and unsuccessful (LeGates \& Stout 2000; Parker 2004).

The term 'gender' came into critical academic usage in the late 1960s and 1970s, and is now well-trod ground in humanities and social science literature. As commonly understood, contrary to the term 'sex', 'gender' serves a useful purpose in distinguishing those aspects of life that are more easily attributed to - or understood to be of - social and cultural rather than biological origin (cf. Deaux 1985; Unger \& Crawford 1992). More specifically, 'gender' refers to the socially and culturally defined differences between women and men, the relationships between them, the diversity and relativity of their roles within the community, and the social negotiations and power structures in which they are embedded (cf. Butler 1990). In line with this, Butler (1990) and Lorber (1995) conceived of 'gender' as a social construction and institution, and one of the main principles of societal order.

Liinason (2010) argued that discursive gender construction pursues quite multifarious approaches in academia. Studies by Moss and Al-Hindi (2008) and Lavena and Riccucci (2012) indicated that gender mainstreaming is contested and surrounded by ambiguities, paradoxes and counteractions from critical perspectives of organizational theory (stressing transformative gender-equality strategies via policy and practice, cf. Rees 1998, 2005), poststructuralist social movement theory (focusing on the socio-political power relationships in achieving gender-differentiated policy awareness, cf. Mazey 2000) and feminist theory (emphasizing diversity as a socio-cultural construction of sex without over-fetishizing immanent equalities and differences between men and women, cf. Harding 2004; Kronsell 2005).

The above theories move beyond trivial and indiscriminate generalizations in that they deconstruct 'the' needs of women in particular and show the fluidities of gender construction. Analogously, scholars do not deal with one and the same gender subject, but discuss 'gender proper', 'gender sensitivity', 'gender mainstreaming' or 'gender equality'. The discourses on gender are complicated by a mixture of analytical and political conceptions stemming from sundry structuralist and poststructuralist ontological and epistemological dispositions. Thus, as inferred from Walby (2005a, 2005b), Verloo (2006, 2007) and Eriksson (2010), gender and gender sensitivity/ mainstreaming/equality are interrelated at the analytical and empirical level, and as such they are discursively and socially constructed and contested.

West and Zimmermann (1987) imparted that the human production of space depends upon everyone's constantly 'doing' gender (see also Butler 1990). They posited that the social construction of gender affects all aspects of life and hence the culture of urban governance. West and Zimmermann (1987) and Bayes et al. (2001) moreover claim that people's knowledge of gender constructs can be enhanced through an alteration in education and institutional culture. This is rather challenging, however, as gender is mostly 'done' unconsciously, on top of which everyday environ- 
mental practices often neutralize gender, as conveyed by Rocheleau et al. (2006).

As derived from Booth and Benneth (2002) and Lavena and Riccucci (2012), this article takes gender mainstreaming governance as the process of making gender-sensitive criteria a routine element in the development of organizations, plans and policies in relation to the social environment. Originally inspired by feminist theory, gender mainstreaming has been employed as a publicpolicy strategy since the 1990s (cf. True 2003; Lavena \& Riccucci 2012). Although gender mainstreaming entails a contested approach and a plethora of ambiguous notions (cf. Walby 2005a, 2005b), gender theorists are usually aware that the interface between gender mainstreaming and societal change needs a stronger articulation (cf. Daly 2005). If governance implies the idea of a plurality of actors involved at different steps and levels in the programming and implementation of policies, it is apparent that the degree to and the way in which gender is incorporated into practices of urban governance become crucial (Council of Europe 1998; European Commission 2009). Here, the main challenge for urban governors is to avoid reinforcing stereotypes along the lines of sex and gender.

Daly (2005) and Lavena and Riccucci (2012) indicate that gender issues are still on the periphery rather than at the centre of both theories and practices of urban governance. For all that, there has been progress since the 1960s in rendering and implementing academic work on gender into practice, primarily within the scope of European integration (Cavanagh 1998; Kronsell 2005). Modifications should go beyond merely adjusting the built environment as such (Fenster 1999; Darke et al. 2000). Sandercock and Forsyth (1992), Greed (2003) and Hafner-Burton and Pollack (2009) stressed the need to make changes in gender awareness in a wider sense, namely in education and in the culture of urban and regional planning and governance, think moreover of community engagement and joined-up governance (which are all highly differentiated and multiscalar in themselves, cf. Yúdice 2003; Swyngedouw 2005; Biesta 2011; Healey 2012). LeGates and Stout (2000: 447) noted the academic responsibility for increasing gender awareness: "research and theory building can help change the culture of planning so that gender considerations become an accepted part of practice by all planners, male and female."
The challenge in this context is to identify, operationalize and apply gender-differentiated methods in a coherent and consistent fashion that enjoys rapport with societal communities at large. Nonetheless, as expressed by Daly (2005), such a translation of gender mainstreaming into urban governance is seen as an obstacle rather than a challenge:
"The lack of clarity in the concept/approach at the present time is causal. It provides fertile ground for political expediency, for example - because mainstreaming is so elastic, it is easy to make a claim to be doing mainstreaming. In addition, one could attribute the tendency toward technocrati- zation to lack of clarity in definition and concep- tualization." (ibid: 439)

That said, gender mainstreaming - technocratic in approach or not - has gained socio-political importance since WWII. Western gender criticism of urban governance, and hence gender awareness, arose in the urban sphere as well as urban literature in the 1950s and 1960s (Hayden 1980; Parker 2004; Essed et al. 2009), when feminists began to criticize the physical and social constraints that cities put particularly on women.

On the basis of Sandercock and Forsyth (1992), McDowell (1997), Cavanagh (1998), Booth and Bennett (2002) and Lavena and Riccucci (2012), one can discern three important theoretical developments on the topic of gender in urban governance over the last 40 years. First, a shift in focus from women as carers to women as carers and waged workers took place as a result of this new double role that women had achieved in society. Secondly, initially stress was often laid on just the differences between women and men, whereas attention is now paid to diversity within especially the group of women; not every woman is, for instance, a white, heterosexual, middle-class homemaker. Thirdly, the terminology of gender, and consequently its methodological structure, was modified. What began as 'women and urban governance' became 'equal opportunities' and then 'gender sensitivity' and 'gender mainstreaming'. The last two terms basically imply the move from difference thinking towards gender reasoning, in which an attempt is made to stress and treat both women's and men's needs evenly, impartially and dialectically.

In the mid-1970s, considerable difficulties arose from the change in the traditional family pattern in the western world. Substantially more 
women took up paid labour, and this permanently altered their mobility and space needs. However, the conventional homes and built environment did not fully satisfy the needs of employed women in particular. Since then, women's restrictions in space (in respect of e.g. commuting, safety/violence, childcare and leisure) have been one of the main topics in the literature and policy discourse on gender and urban governance (Hayden 1980; Huairou Commission and UN-Habitat 2004).

Influential gender pioneers like Dolores Hayden started to explore the interrelationships between gender, class and power in the built environment in the 1970s. Inspired by Marxist literature on spatial design, Hayden (1980) made a plea for enabling women to become equal members of society by assailing the accustomed division between public and private space. Hayden managed to link human activity to geographical scales, and in doing so focused on the differentiation between particularly women and all their assorted needs in time and space (cf. Hayden 1980; Sandercock \& Forsyth 1992, see also Scholten et al. 2012).

Women's and men's lives - their work, earned income, situated roles, shared relationships, and so on - are shaped by social norms and traditions that treat women and men differently. The attributes, needs and desires of women and men, and the way in which they shape social, political and economic life, differ among as well as between women and men, which should be reckoned with in gender awareness (Hayden 1980; Beall 1996; Parker 2004). Hayden's (1980) main criticism of the modern built environment was that it underrepresents 'good' neighbourhoods: living areas that unite the services, housing and jobs that are demanded by both men and women in all their diversities (cf. Huairou Commission and UN-Habitat 2004).

Such gender mainstreamed space is one of the goals of the EU (cf. European Commission 2000; Lombardo \& Meier 2008). However, Lavena and Riccucci (2012: 134) stated that the EU has made "less progress in terms of results", especially on the deep-seated social level, despite its implementation of gender-sensitive policy regulations. They ascribed this lack of progress to the non-coherent ways in which diverse EU regimes conceptually and practically engage with gender mainstreaming, and to the complex, contradictory and multiscalar reality of gender mainstreaming governance, which ranges from local to regional, national and global levels (ibid.).

\section{Sweden and Italy: differentiated perspectives on gender mainstreaming}

In the purview of gender mainstreaming urban governance in Europe, there is, relatively seen, a considerable contrast between the political policy histories of Sweden and Italy. Whereas Sweden broadly embodies a highly developed welfarestate regime (cf. Anxo et al. 2007), Italy generally harbours a highly familistic welfare-state regime that corresponds to a traditional society in which women are predominantly typified as carers (cf. Hamnett 1996; Anxo et al. 2007). In addition to the differentiating notes as given in the introduction to this article, the differences between Swedish and Italian gender mainstreaming urban governance, and the internal differences on both sides, should also be delicately understood from the various roles and related social and legal responsibilities of local authorities that are in interplay with regional and national governments, as further contextualized in the following.

The chief participatory channel in urban governance is through political and institutional bodies (Droste et al. 2005). In both countries, principally some women's groups have established bottom-up, grassroots initiatives in order to mainstream gender in the political and institutional realm. Despite empowerment-oriented movements like these, EU gender-equality pacts, in juxtaposition to Sweden, usually still challenge the gender sensitivity of urban governance practices in Italy (cf. Anxo et al. 2007; Pettersson 2012). On this, it should be acknowledged that urban policies are normally beyond the EU's competences. Nevertheless, some urban policy programmes, such as URBAN, are formally embedded in the EU (cf. Tofarides 2003). The EU has, moreover, the potential to advocate regional and urban policies, including gender-sensitive initiatives, and thus to be a public educator in this context (cf. Biesta 2011; Lavena \& Riccucci 2012).

According to Hamnett (1996), Droste et al. (2005) and Rizza and Sansavini (2010), over the last 20 years a gender-sensitive approach has been gradually incorporated into the political and social culture of the Italian regime, and consequently into urban governance. On the basis of their insights, to boot, one can find that although the Italian political landscape is increasingly regionally polarized and political power chiefly remains a male privilege in Italy today, the female presence 
in politics and urban administration in particular is increasing due to a generally augmenting permissive mindset (for facts and figures on Italy's genderequality machinery in multilevel governance, see Guadagnini \& Donà 2007; Ortbals et al. 2011). This may have a positive influence on policy commitment to social welfare and cultural difference (cf. Chen 2010, and see notes on Italy in Krook \& Childs 2010). Even so, it should be argued that, over the last 20 years, the Italian gender-permissive mindset has found itself doing battle with antiprogressive tactics and policies, also related to the domestic sphere, which has restrained the potential to further implement gender-sensitive approaches in the political arena and to promote alternative gender imageries in Italian society (cf. Saraceno 1994; Guadagnini \& Donà 2007).

Although the female presence in Italian urban governance is still quite modest as compared to Sweden, there is gender improvement in Italy particularly on account of the opportunities provided by two objectives of legislative intercession. Namely, the further closing of gender gaps in education and at the professional level, and the supply of ad hoc institutions supervising the implementation of gender-equality rationales, which includes the provision of workshops on job training, and campaigns aimed at combatting gender violence and improving the health of women (Ortbals et al. 2011, see also Droste et al. 2005). These legislative endeavours, stirred by the Ministry of Equal Opportunities and the National Committee for Equal Opportunities at Work, are supposed to advance equal socio-economic opportunities regarding work, education, entrepreneurship, provision for maternity and paternity, and the like. Not only do such top-down endeavours matter, but so too do the responsibilities and powers of regional governments, above all in the fields of transport, planning, social services and healthcare. Gender policies in these fields are mainly instituted at the regional level; municipal gender-sensitive incentives are less common (cf. Barbera \& Vettor 2001; Zajczyk 2003; Anxo et al. 2007).

A prominent empirical example of gender mainstreaming urban governance in Italy is the case of proper working time schedules, which were first drawn up after the public administration reform of the early 1990s. Although the contents of Italian urban gender policies are generally forward-looking, as they include gender-inclusive socio-spatial interventions, the gender approach tends to be rather expedient, and, more fundamentally, re- mains within the sphere of male-dominated decision making and corporate governance (cf. Ponzellini 2006).

Furthermore, in contrast to Sweden, a substantial share of Italian gender-sensitive initiatives and policies are dependent on the actions of single local actors like mayors and other city managers (cf. Mattei 2007); this has especially been the case since the 2001 constitutional reform, when municipalities gained more autonomy (cf. Argento et al. 2010). In Italy, gender mainstreaming within urban governance often lacks synergy, a coherent and strategic vision, and accurate action planning (cf. Zajczyk 2003; Droste et al. 2005). Moreover, in comparison with Sweden, in Italy there is a dearth of statistical information - and therefore evidence - on female representation in decision making and the overall condition of women. This lack of statistics, however, does not prevent Italian policy innovations from engaging in gender mainstreaming (cf. Statistical Commission and Economic Commission for Europe 2000; Guadagnini \& Donà 2007; Rizza \& Sansavini 2010).

Gender is historically strongly mainstreamed in Swedish social policies (Hamnett 1996). Saliently, Sweden has one of the world's highest proportions of women in decision-making positions at the national, regional and local level (for facts and figures, see UNCHS 2001; Anxo et al. 2007; European Commission 2012). Over the last 35 years, Sweden has implemented advanced gender-equality policies, albeit through a rather top-down, prescriptive legislative framework. Considerable policies are the Equal Opportunities Act of 1991 and its related national, regional and local mainstreaming schemes. These policies have been followed through with specific strategies, pilot projects and gender-training courses in the public domain with the purpose of increasing gender parity and awareness (cf. Division for Gender Equality 2005; Anxo et al. 2007; European Institute for Gender Equality 2012).

The Swedish equity planning has acknowledged the innumerable conflicting social interests within a transforming society. Through their recognition of marginalized interests, the far-reaching Swedish equity planning and policymaking have interlinked feminist planning criticism, the deconstruction of dualist conceptions of gender in societal power relations, and the gender mainstreaming strategy as an instrument to change these relations in a drastic, socio-politically inclusive way (cf. Lister 2003; Droste et al. 2005; Liinason 2010). 
As an empirical illustration, national schemes run by the Swedish Agency for Economic and Regional Growth promote women's entrepreneurship, and are intrinsically aimed at gender inclusiveness at all levels of government (cf. European Commission 2012; Pettersson 2012). Moreover, municipalities organize projects on gender equality, which primarily touch on matters related to female representation in decision making (cf. Woodward 2003). Local Development Agreements (LDAs), furthermore, have been implemented in Sweden to stimulate civic participation and incite the deeper and broader citizenship of both women and men. For example, LDAs have enabled the foundation of women's policy agencies which are also encouraging initiatives by distinct local communities that include women of different ethnic origins, who might experience discrimination (think specifically of migrants and ethnic minorities). LDAs have additionally led to metropolitan programmes at the meso-level that are intended to boost gender parity and articulate and cherish gender differences among the urban population by combating segregation along economic, social and ethnic lines (cf. Lukkarinen 2004; Schulz et al. 2007). Despite these endeavours, there is some criticism in Sweden regarding the allegedly inadequate capacity of Swedish welfare communities to achieve full diversity, owing to their prioritization of gender over other socio-cultural inequalities concerning, for example, class and ethnicity (cf. Siim 2007; Borchorst \& Siim 2008).

\section{Concluding remarks}

The comparative findings of this research have shown that the key factor in creating opportunities - or rather constraints - for mainstreaming gender into urban governance bears on the institutionalization of gender mainstreaming. In Sweden, gender mainstreaming is considerably more interwoven with the socio-political fabric than is the case in Italy. The most important reason for this lies in the much longer Swedish democratic tradition of incremental egalitarian planning and policymaking in practices of urban governance, and in Sweden's overall higher political pressure on gender-sensitive practices. As also inferred from Guadagnini and Donà (2007), Borchorst and Siim (2008), the European Commission (2000, 2011, 2012), Ortbals et al. (2011) and Pettersson (2012), other underlying reasons are the comparatively higher educational level of women in Sweden and their commonly stronger capacity to empower themselves (which is related to the remarkably more pronounced double role of Swedish women as carers and waged workers); the relatively low level of female political participation in Italy, which in general has led to a paucity of gender awareness; the rather more ad hoc instruments for implementing gender mainstreaming policies in Italy; and the substantially more male-streamed culture of urban governance in Italy, which to a large extent depends upon its widespread traditional, patriarchal society. All in all, Sweden has witnessed a comparatively stronger institutionalization of gender awareness and a more structural embedding of gender mainstreaming within urban governance than Italy.

Although the gender sensitivity of urban governance in Sweden can by and large be regarded as fairly strong, there is, as is the case in Italy, a certain lack of gender awareness, particularly regarding women's safety in land-use planning (cf. Sandercock \& Forsysth 1992; Anxo et al. 2007). This lack is often considered part and parcel of the largely male-streamed European society (cf. Ottes et al. 1995; Rees 2005). In both Sweden and Italy, the impact of gendersensitive policies varies across urban governance fields, and on that account there remains a plethora of gender gaps. Strikingly, and perhaps relatedly, the level of female socio-political participation in institutionalized 'classic' domains like public transport is relatively lower than in 'unconventional', participatory-based domains such as community building (cf. Carlsson-Kanyama et al. 1999; Droste et al. 2005; Anxo et al. 2007).

Furthermore, as a general challenge within the European context of urban governance, Lavena and Riccucci (2012) stated that the current economic crisis has indirectly led European countries and regional and local governments to prioritize economic competitiveness over gender diversity and awareness in public policy, and as a result, the gender neutrality of European policies should be questioned (see also Woodward \& Meier 1998 for gender impact assessment in the changing socio-political landscape of Europe). In addition, the degree of public willingness to report cases of gender discrimination puts another 
complexion on the matter (cf. Lavena \& Riccucci 2012).

This study suggests that using the interstices left by the programmes and policies of urban governance to intertwine top-down and bottom-up structures and initiatives - and hence interlink actions - might produce the most effective results as far as gender mainstreaming in the city is concerned. In the light of such 'good' urban governance, the regional, the national and the supranational EU level could together play an essential role in fostering and revving up policies apropos of gender sensitivity from above. At the same time, 'good' urban governance should further stimulate the role of civil society actors and public movements in advocating and reifying gender mainstreaming in local policy and planning.

This article is work in progress and argues that further, deeper research is needed on the sociospatial construction of gender issues in urban policymaking and their regional differences. On this, nuanced critical insight is required into people's social and cultural backgrounds, including class, race, ethnicity, sexuality, religion, age and ability/disability (cf. European Commission 2009; Brown 2012; Leslie \& Catungal 2012), and their resources and knowledges in time and sociophysical as well as virtual spaces (cf. Green \& Adam 2001, see Haraway 2004 for 'situated knowledges' as a helpful epistemological and methodological tool in such endeavour). This would make 'doing' gender in both academia and urban governance a plausible outlook for citizenship in a post-nationalist vein more broadly (cf. Braidotti 2010) and sexual citizenship in particular (cf. Mann 2013; Zebracki 2014). Such intellectual as well as 'real-world' gender mainstreaming (cf. Mazey 2000) relies on the awareness of the gender-differentiated public as the ultimate voice in the formulation of policy and planning means and ends.

\section{ACKNOWLEDGEMENTS}

While any errors are my own, I should like to thank the anonymous referees and the editor Paola Minoia for their useful comments on earlier versions of this manuscript. This research was conducted in the Cultural Geography Group at Wageningen University and received no specific grant from any funding agency.

\section{REFERENCES}

Anxo D, Flood L, Mencarini L, Pailhé A, Solaz A \& Tanturri M 2007. Time allocation between work and family over the life-cycle: a comparative gender analysis of Italy, France, Sweden and the United States. Institute for the Study of Labor, Bonn.

Argento D, Grossi G, Tagesson T \& Collin S 2010. The 'externalisation' of local public service delivery: experience in Italy and Sweden. International Journal of Public Policy 5: 1, 41-56. http://dx.doi. org/10.1504/IJPP.2010.029780.

Barbera M \& Vettor P 2001. The case of Italy. In Behning $U$ \& Pascual $A$ (eds). Gender mainstreaming in the European employment strategy, 259-272. European Trade Union Institute, Brussels.

Bayes J, Hawkesworth M \& Kelly R 2001. Globalization, democratization and gender regimes. In Kelly R, Bayes J, Hawkesworth M \& Young B (eds). Gender, globalization and democratization, 1-14. Rowman and Littlefield, Boulder.

Beall J 1996. Urban governance: why gender matters. United Nations Development Programme (UNDP) Gender in Development Monograph Series 1. United Nations Development Programme, New York.

Becker R 2003. What's wrong with a female head? The prevalence of women-headed households and its impact on urban development and planning. In Terlinden U (ed). From the local level to the global level and back again. City and gender: international discourse on gender, urbanism and architecture, 151-173. Leske und Budrich, Opladen.

Biesta G 2011. The ignorant citizen: Mouffe, Rancière, and the subject of democratic education. Studies in Philosophy and Education 30: 2, $141-$ 153.

http://dx.doi.org/10.1007/s11217-011-9220-4.

Booth C \& Bennett C 2002. Gender mainstreaming in the European Union: towards a new conception and practice of equal opportunities? European Journal of Women's Studies 9: 4, 430-446. http://dx.doi.org/10.1177/13505068020090040 401.

Borchorst A \& Siim B 2008. Woman-friendly policies and state feminism: theorizing Scandinavian gender equality. Feminist Theory 9: 2, 207-224. http://dx.doi.org/10.1177/1464700108090411.

Braidotti R 2010. European citizenship: a post-nationalist perspective. In May T (ed). The history of continental philosophy: emerging trends in continental philosophy, 127-148. Acumen, Durham.

Brenner N 2004. Urban governance and the production of new state spaces in western Europe, 1960-2000. Review of International Political Economy 11: 3, 447-488. http://dx.doi.org/10.1 080/0969229042000282864.

Brown M 2012. Gender and sexuality I: intersectional anxieties. Progress in Human Geography 36: 4, 541550.http://dx.doi.org/10.1177/0309132511420973. 
Butler J 1990. Gender trouble: feminism and the subversion of identity. Routledge, London.

Carlsson-Kanyama A, Lindén A \& Thelander Å 1999. Insights and applications: gender differences in environmental impacts from patterns of transportation - a case study from Sweden. Society \& Natural Resources: An International Journal 12: 4, 355-369.

http://dx.doi.org/10.1080/089419299279641.

Cavanagh S 1998. Women and the urban environment. In Greed C \& Roberts M (eds). Introducing urban design: interventions and responses, 168177. Longman, Essex.

Chant S 2013. Cities through a "gender lens": a golden "urban age" for women in the global South? Environment and Urbanization 25: 1, 9-29. http:// dx.doi.org/10.1177/0956247813477809.

Chen L 2010. Do gender quotas influence women's representation and policies? The European Journal of Comparative Economics 7: 1, 13-60.

Ciccia R \& Verloo M 2011. Who cares? Patterns of leave regulation in an enlarged Europe: using fuzzy-set ideal types to assess gender equality. Institut für die Wissenschaften vom Menschen, Quality in Gender+ Equality Policies (QUING), Vienna.

Council of Europe 1998. Gender mainstreaming: conceptual framework, methodology and presentation of good practices. Council of Europe, Strasbourg.

Daly M 2005. Gender mainstreaming in theory and practice. Social Politics: International Studies in Gender, State \& Society 12: 3, 433-450. http:// dx.doi.org/10.1093/sp/jxi023.

Darke J, Ledwith S \& Woods R 2000. Women and the city: visibility and voice in urban space. Palgrave, Oxford.

Dean M 1999. Governmentality: power and rule in modern society. Sage, Los Angeles.

Deaux K 1985. Sex and gender. Annual Review of Psychology 36: 1, 49-81. http://dx.doi. org/10.1146/annurev.ps.36.020185.000405.

Division for Gender Equality 2005. Gender equality in Sweden - a summary. <http://www.epfound. am/files/sweden_gender_equality.pdf> 19.03.2013.

Doan P 2010. The tyranny of gendered spaces - reflections from beyond the gender dichotomy. Gender, Place \& Culture 17: 5, 635-654. http:// dx.doi.org/10.1080/0966369X.2010.503121.

Droste C, Molina I \& Zajczyk F 2005. Restructuring large housing estates: does gender matter? In Van Kempen R, Dekker K, Hall S \& Tosics I (eds). Restructuring large housing estates in Europe, 299320. The Policy Press, Bristol.

Eriksson A (ed) 2010. Equality, growth \& sustainability: do they mix? Linköping Electronic Conference Proceedings, No. 58. Forum for Gender Studies and Equality, Linköping University, Linköping. <http://liu.diva-portal.org/smash/get/ diva2:413708/FULLTEXT02.pdf> 05.04.2013.
Esping-Andersen G 1990. The three worlds of welfare capitalism. Polity Press, Cambridge.

Essed P, Goldberg D \& Kobayashi A 2009. A companion to gender studies. Wiley-Blackwell, Malden.

European Commission 2000. Gender equality in the European Union: examples of good practices (1996-2000). Office for Official Publications of the European Communities, Luxembourg.

European Commission 2009. Gender mainstreaming active inclusion policies. <http://www.isotita.gr/ var/uploads/POLICIES/PLHROFORIAKO\% 20 YLIKO/Gender\% 20mainstreaming \% 20active\%20inclusion \%20policies_EC_2010.pdf> 11.02.2013.

European Commission 2011. Data and information on women's health in the European Union. <http://ec.europa.eu/health/population_groups/ docs/women_report_en.pdf>18.01.2013.

European Commission 2012. Women in economic decision making in the EU: progress report. <http://ec.europa.eu/justice/gender-equality/ files/women-on-boards_en.pdf> 16.01.2013.

European Institute for Gender Equality 2012. Mapping of gender training policies and practices in the European Union. Summary of findings. $<$ http://eige.europa.eu/sites/default/files/Gender\%20Training\% 20-\%20Summary\%20of\% 20 findings.pdf>08.02.2013.

Fenster T (ed) 1999. Gender, planning and human rights. Routledge, New York.

Gabaccia D \& Maynes M (eds) 2013. Gender history across epistemologies. Wiley-Blackwell, Oxford.

Greed C 2003. The rocky path: 'from women and planning' to gender mainstreaming. Faculty of the Built Environment, University of the West of England, Bristol.

Green E \& Adam A (eds) 2001. Virtual gender: technology, consumption and identity. Routledge, London.

Guadagnini M \& Donà A 2007. Women's policy machinery in Italy between European pressure and domestic constraints. In Outshoorn J \& Kantola J (eds). Changing state feminism, 200-230. Palgrave, New York.

Gustafsson R \& Szebehely M 2009. Outsourcing of elder care services in Sweden: effects on work environment and political legitimacy. In King D \& Meagher G (eds). Paid care in Australia: politics, profits, practices, 81-112. Sydney University Press, Sydney.

Hafner-Burton E \& Pollack M 2009. Mainstreaming gender in the European Union: getting the incentives right. Comparative European Politics 7: 1, 114-138. http://dx.doi.org/10.1057/cep.2008.37.

Hamnett C 1996. Social polarisation, economic restructuring and welfare state regimes. Urban Studies 33: 8, 1407-1430. http://dx.doi.org/10.1080/0042098966727.

Haraway D 2004. Situated knowledges: the science question in feminism and the privilege of partial perspective. In Harding S (ed). The feminist standpoint theory reader: intellectual and political controversies, 81-102. Routledge, New York. 
Harding S (ed) 2004. The feminist standpoint theory reader: intellectual and political controversies. Routledge, New York.

Hayden D 1980. What would a non-sexist city be like? Speculations on housing, urban design, and human work. Signs: Journal of Women in Culture and Society 5: 3, 170-187. http://dx.doi. org/10.1086/495718.

Healey P 2012. The universal and the contingent: some reflections on the transnational flow of planning ideas and practices. Planning Theory 11: 2, 188-207. http://dx.doi.org/10.1177/1473095211419333.

Huairou Commission and UN-Habitat 2004. Local to local dialogue: a grassroots women's perspective on good governance. Urban governance toolkit series. UN-Habitat, Nairobi.

Jarvis H, Cloke J \& Kantor P 2009. Cities and gender. Routledge, New York.

Jessop B 2002. Liberalism, neoliberalism, and urban governance: a state-theoretical perspective. Antipode 34: 3, 452-472. http://dx.doi.org/10.1111/1467-8330.00250.

Kronsell A 2005. Gender, power and European integration theory. Journal of European Public Policy 12: 6, 1022-1040. http://dx.doi.org/10.1080/13501760500270703.

Krook M \& Childs S (eds) 2010. Women, gender, and politics: a reader. Oxford University Press, New York.

Kröger T 1997. The dilemma of municipalities: Scandinavian approaches to child day-care provision. Journal of Social Policy 26: 4, 485-507. http://dx. doi.org/10.1017/S0047279497005126.

Lang S 2009. Assessing advocacy: European transnational women's networks and gender mainstreaming. Social Politics: International Studies in Gender, State \& Society 16: 3, 327-357. http://dx.doi. org/10.1093/sp/jxp016.

Lavena C \& Riccucci N 2012. Exploring gender mainstreaming in the European Union. International Journal of Public Administration 35: 2, 122-136. http://dx.doi.org/10.1080/01900692.2011.61699.

LeGates R \& Stout F 2000. The city reader. Routledge, London.

Leslie D \& Catungal J 2012. Social justice and the creative city: class, gender and racial inequalities. Geography Compass 6: 3, 111-122. http://dx.doi. org/10.1111/j.1749-8198.2011.00472.x.

Liinason M 2010. Institutionalized knowledge: notes on the processes of inclusion and exclusion in gender studies in Sweden. NORA - Nordic Journal of Feminist and Gender Research 18: 1, 38-47. http://dx.doi.org/10.1080/08038741003626973.

Lin J \& Mele C (eds) 2013. The urban sociology reader. Routledge, New York.

Lister R 2003. Citizenship: feminist perspectives. New York University Press, New York.

Lombardo E \& Meier P 2008. Framing gender equality in the European Union political discourse. Social
Politics: International Studies in Gender, State \& Society 15: 1, 101-129. http://dx.doi.org/10.1093/sp/jxn001.

Lorber J 1995. Paradoxes of gender. Yale University Press, New Haven.

Lukkarinen M 2004. Local development agreements as a tool to stop segregation in vulnerable metropolitan areas: synthesis report. European Commission. <http:// www.euro.centre.org/data/1138964131_1181. $p d f>02.03 .2013$.

Mann E 2013. Regulating Latina youth sexualities through community health centers: discourses and practices of sexual citizenship. Gender \& Society 27: 5, 681-703.

Mattei P 2007. From politics to good management? Transforming the local welfare state in Italy. West European Politics 30: 3, 595-620. http://dx.doi. org/10.1080/01402380701276444.

Mazey S 2000. Introduction: integrating gender — intellectual and 'real world' mainstreaming. Journal of European Public Policy 7: 3, 333-345. http:// dx.doi.org/10.1080/13501760050086062.

McDowell L 1997. Capital culture: gender at work in the city. Blackwell, Oxford.

McDowell L 1999. Gender, identity and place. Understanding feminist geographies. Polity Press, Cambridge.

Meyer M \& Prügl E (eds) 1999. Gender politics in global governance. Rowman and Littlefield, Lanham.

Monk J \& Hanson S 1982. On not excluding half of the human in human geography. The Professional Geographer 34: 1, 11-23. http://dx.doi.org/10.1111/ j.0033-0124.1982.00011.x.

Moss P \& Al-Hindi K 2008. Feminisms in geography: rethinking space, place, and knowledges. Rowman \& Littlefield, Lanham.

Ortbals C, Rincker M \& Montoya C 2011. Politics close to home: the impact of meso-level institutions on women in politics. Publius: The Journal of Federalism 42: 1, 78-107. http://dx.doi.org/10.1093/publius/pjr029.

Ottes L, Poventud E, Van Schendelen M \& Segond von Banchet G (eds) 1995. Gender and the built environment: emancipation in planning, housing and mobility in Europe. Van Gorcum, Assen.

Parker S 2004. From pillar to post: culture, representation and difference in the urban world. In Urban theory and the urban experience: encountering the city, 138-158. Routledge, London.

Pettersson K 2012. Support for women's entrepreneurship: a Nordic spectrum. International Journal of Gender and Entrepreneurship 4: 1, 4-19. http:// dx.doi.org/10.1108/17566261211202954.

Pfau-Effinger B 2004. Development of culture, welfare states and women's employment in Europe. Ashgate, Aldershot.

Ponzellini A 2006. Work-life balance and industrial relations in Italy. European Societies 8: 2, 273-294. http://dx.doi.org/10.1080/14616690600645043.

Raju S \& Lahiri-Dutt K (eds) 2011. Doing gender, doing geography: emerging research in India. Routledge, New Delhi. 
Rees T 1998. Mainstreaming equality. In Watson S \& Doyal L (eds). Engendering social policy. Open University Press, Buckingham.

Rees T 2005. Reflections on the uneven development of gender mainstreaming in Europe. International Feminist Journal of Politics 7: 4, 555-574. http://dx.doi. org/10.1080/14616740500284532.

Rizza R \& Sansavini M 2010. Welfare e politiche di conciliazione: il caso dell'Emilia-Romagna [Welfare and work-life balance policies: the case of Emilia-Romagna]. Sociologia del Lavoro 119, 7896.

Rocheleau D, Thomas-Slayter B \& Wangari E 2006. Gender and the environment: a feminist political ecology perspective. In Haenn N \& Wilk R (eds). The environment in anthropology: a reader in ecology, culture, and sustainable living, 27-33. New York University Press, New York.

Sandercock L \& Forsyth A 1992. A gender agenda: new directions for planning theory. Journal of the American Planning Association 58: 1, 49-59. http://dx. doi.org/10.1080/01944369208975534.

Saraceno C 1994. The ambivalent familism of the Italian welfare state. Social Politics: International Studies in Gender, State \& Society 1: 1, 60-82. http:// dx.doi.org/10.1093/sp/1.1.60.

Scholten C, Friberg T \& Sandén A 2012. Re-reading time-geography from a gender perspective: examples from gendered mobility. Tijdschrift voor Economische en Sociale Geografie 103: 5, 584-600.

http://dx.doi.org/10.1111/j.14679663.2012.00717.x.

Schulz S, Vidén S \& Chandra S 2007. General overview of the problems, needs and solutions in the Swedish urban building envelopes. In Melgaard E, Hadjimichael G, Almeida M \& Verhoef L (eds). COST C16 improving the quality of existing urban building envelopes - needs, 131-139. IOS Press, Amsterdam.

Siim B 2007. The challenge of recognizing diversity from the perspective of gender equality: dilemmas in Danish citizenship. Critical Review of International Social and Political Philosophy 10: 4, 491-511. http://dx.doi.org/10.1080/13698230701660196.

Statistical Commission and Economic Commission for Europe 2000. Making gender mainstreaming a national priority. Working paper no. 14. <http://www. unece.org/fileadmin/DAM/stats/documents/2000/10/gender/14.e.pdf> 11.03.2013.

Stone A 2010. Diversity, dissent, and decision making: the challenge to LGBT politics. GLQ: A Journal of Lesbian and Gay Studies 16: 3, 465-472. http://dx. doi.org/10.1215/10642684-2009-040.

Swyngedouw E 2005. Governance innovation and the citizen: the Janus face of governance-beyond-thestate. Urban Studies 42: 11, 1991-2006. http:// dx.doi.org/10.1080/00420980500279869.

Tofarides M 2003. Urban policy in the European Union: a multi-level gatekeeper system. Ashgate, Aldershot.

True J 2003. Mainstreaming gender in global public policy. International Feminist Journal of Politics 5: 3,
368-396. http://dx.doi.org/10.1080/14616740320 00122740.

True J \& Mintrom M 2001. Transnational networks and policy diffusion: the case of gender mainstreaming. International Studies Quarterly 45: 1, 27-57. http:// dx.doi.org/10.1111/0020-8833.00181.

Tuori S 2007. Cooking nation: gender equality and multiculturalism as nation-building discourses. $E u-$ ropean Journal of Women's Studies 14: 1, 21-35. http://dx.doi.org/10.1177/1350506807072315.

UNCHS 2000. Policy paper on women and urban governance. <http://www1.aucegypt.edu/src/engendering/Documents/Home\% 20Page/women\%20 and\%20urban\%20governance.pdf> 04.05.2013.

UNCHS 2001. Urban governance. Women in local leadership. <http://www.un.org/ga/lstanbul+5/102.pdf> 27.05.2013.

Unger R \& Crawford M 1992. Women \& gender: a feminist psychology. McGraw-Hill, New York.

Verloo M 2006. Multiple inequalities, intersectionality and the European Union. European Journal of Women's Studies 13: 3, 211-228. http://dx.doi. org/10.1177/1350506806065753.

Verloo M 2007. Multiple meanings of gender equality: a critical frame analysis of gender policies in Europe. Central European University Press, Budapest.

Walby S 2005a. Gender mainstreaming: productive tensions in theory and practice. Social Politics 12: 3, 321-343. http://dx.doi.org/10.1093/sp/jxi018.

Walby S 2005b. Introduction: comparative gender mainstreaming in a global era. International Feminist Journal of Politics 7: 4, 453-470. http://dx.doi. org/10.1080/14616740500284383.

Watson S \& Gibson K 1995. Postmodern cities and spaces. Blackwell, Oxford.

West C \& Zimmermann D 1987. Doing gender. Gender \& Society 1: 2, 125-151. http://dx.doi.org/10.1177/ 0891243287001002002.

Woodward A 2003. European gender mainstreaming: promises and pitfalls of transformative policy. Review of Policy Research 20: 1, 65-88. http://dx. doi.org/10.1111/1541-1338.d01-5.

Woodward A \& Meier P 1998. Gender impact assessment: a new approach to changing policies and contents of citizenship? In Ferreira V, Tavares T \& Portugal S (eds). Shifting bonds, shifting bounds: women, mobility and citizenship in Europe, 95106. Celta, Oeiras.

Yúdice G 2003. The expediency of culture: uses of culture in the global era. Duke University Press, Durham.

Zajczyk F 2003. La povertà a Milano. Distribuzione territoriale, servizi sociali e problema abitativo [Poverty in Milan. Geographical distribution, social services and housing issues]. F. Angeli, Milan.

Zebracki M 2014. Explosive multiscalar negotiations of sexual citizenship: the 2014 Russian Winter Olympics countdown. Antipode <http:// antipodefoundation.org/2014/02/07/the2014-russian-winter-olympics-countdown/> 07.02.2014. 